\title{
MASS COMMUNICATION SCIENCES IN THE MAGHREB: A HYBRID IDENTITY FOR AN EVOLVING DISCIPLINE
}

\author{
KAMAL HAMIDOU \\ QATAR UNIVERSITY
}

\begin{abstract}
Throughout the world, mass communication sciences had faced many difficulties to impose itself in the academic and administrative spheres as a new, entirely independent discipline. Even nowadays, certain fierce opponents still refuse to admit that it is a discipline, claiming that it is only a field. Indeed, the discipline is now established and well recognized in the major countries of the world, but it did not undertake the same path in all parts of the world. This article discusses the issue of Mass Communication Sciences' state in Maghreb. It focuses on the historical, political, academic and administrative considerations which influenced its progress in three countries, namely: Algeria, Tunisia and Morocco. The purpose is to identify the influences that marked the advent and development of the discipline in the region. The study found out that Mass Communication Sciences in the Maghreb suffered from the lack of visibility on its identity; this is essentially due to the name given to the discipline 'Information and Communication Sciences', inherited from the French administration as the former colonizing or protective state of the three countries. The study also highlights the ambiguity which accompanied the establishment of a discipline that first emerged from the reduced 'journalism' appellation, and finds itself secondly considered as a simple branch of Political Sciences, which poses the question of its legitimacy in academic decision makers' minds. Finally, the study underlines the impact of the absence of professional associations able to defend the interests of the discipline and to represent it within the different administrative or academic decision levels, either in the three single countries or at a regional level.
\end{abstract}

Keywords: Mass communication advent, mass communication identity, mass communication legitimacy, mass communication discipline, critical vs. empirical approaches.

\section{KOMUNIKASI MASSA SAINS DI MAGHRIBI: SATU IDENTITY HIBRID DALAM DISIPLIN YANG SERING BERUBAH}

\begin{abstract}
Abstrak
Secara globalnya, sains komunikasi massa telah melalui banyak kesulitan untuk menonjolkan diri dalam sfera akademik dan pentadibiran sebagai disiplin yang baru dan bebas. Sehingga sekarang masih ada pembangkang yang tegar yang tidak mahu mengakui bahawa ia adalah satu bidang bukan disiplin. Hakikatnya disiplin ini telah kukuh dan amat dikenali umum dalam negara besar dunia, namun tidak mengambil jalan yang sama dalam dunia. Artikel ini membincangkan isu komunikasi massa di negara Maghribi. Ia berfokus pada sejarah, politik, akademik dan pentadbiran yang mempengaruhi pembangunannya di tiga negara iaitu Algeria, Tunisia and Morocco. Tujuannya ialah untuk mengenalpasti pengaruh yang menandai kemunculan dan pembangunan disiplin serantau tersebut. Hasil kajian mendapati sains komunikasi massa merasa terhimpit kerana mendapat perhatian terhadap identiti; hakikat ini kerana nama yang diberi pada disiplin "Sains Maklumat dan Komunikasi' diperolehi dari pentadbiran Perancis yang pernah menjajah ketia-tiga negara tersebut. Kajian ini juga menerangkan kekaburan yang mengikuti penubuhan disiplin yang mula tercipta dari sebutan jurnalisma yang dianggap sebagai sebahagian dari sains politik yang mengemukakan persoalan kewujudannya dalam
\end{abstract}


pemikirian pembuatputusan akademik. Akhir sekali, kajian ini menjadi dasar kepada impak ketidakwujudan persatuan untuk melindungi tujuan disiplin ini dan untuk menjadi wakil dalam pelbagai peringkat pembuatputusan pentadbiran mahupun akademik, samada dalam tiga negara yang disebutkan atau pun di pringkat serantau.

Kata kunci: Kemunculan komunikasi massa, identiti komunikasi massa, kesahihan komunikasi massa, disiplin komunikasi massa, pendekatan kritikal vs empirical.

\section{INTRODUCTION}

One does acknowledge that Mass Communication Sciences is a new discipline (Ugboajah, 1987) founded about just ninety years ago. The base was long to set up. Indeed, the discipline itself had to be invented in first place - which was done by 'the founding fathers' in the first half of the $20^{\text {th }}$ century. Then, other contributors progressively structured what was considered at that time to be a simple field (Shramm, 1959), by endowing it with specific problematic and appropriate methods and tools. Yet, Mass Communication was not totally stated as an independent discipline with an universally recognized legitimacy and fully stated identity.

The elusive nature of this discipline comes from the fact that the first cornerstones have been placed by fathers who belonged to bordering fields or disciplines ; the majority of them came from neighbouring disciplines such as Political Sciences, sociology, psychology, mathematics, telecommunication, etc. (Katz, 1987) - who can be considered as one of the latest founding fathers rightly described Mass Communication as a Greek soap opera, arguing that "first, it has many putative fathers, none of whom is rushing forward to claim paternity; second, because the baby is kidnapped or lost and later found, grown and attractive, on some other ranch, unaware of the grand heritage it is carrying; third, because we, the viewers, know that the clue to the identity of the true father is revealed by observing whom the offspring are trying to do in" (p.10). The problem of Mass Communication identity became more complicated to solve because of the epistemological and methodological oppositions between the US tradition of Mass Communication and the European tradition built up in the second half of the $20^{\text {th }}$ century (Gitlin, 1978). The first one, of functionalist inspiration, emphasises the sociological and psychological approaches of the media, while the second one, of critical inspiration, stresses the historical, legal, linguistic and philosophical aspects of the discipline. 
In France, - former colonizing and protecting state of the three Maghrebian countries which form the geographical subject of our study : namely, Algeria, Morocco and Tunisia - it is the linguistic approach of Barth and the structural anthropology of Levi-Straus that dominated research in Mass Communication, before it turned towards the path of reception, cognition and ICTs at the end of the $21^{\text {st }}$ century (Miege, 2004). Moreover, Mass Communication Sciences as a full university discipline were recognized in Metropolitan France only recently, in 1975, when the University Consultative Committee (CCU) classified them in the $52^{\text {nd }}$ section (Winkin, 2004), before the recently established National University Council (CNU) classified them in the $71^{\text {st }}$ section in 1983 (Jeanneret, Y.; Ollivier, 2004)

Thus, we can, in full logic, formulate the assumption that Mass Communication as an academic discipline has taken, in the three Maghrebian countries, the same direction taken by the French Mass Communication, as the three concerned countries inherited in this field educational institutions and education curricula set up by the former colonizing and/or protective power. Therefore, this study proposes to check the validity of this assumption by carrying out an inventory of Mass Communication Sciences in Algeria, Morocco and Tunisia, since the launching of the discipline in these countries up to now.

\section{METHODOLOGY}

By using a historical approach, we analyze the historical variables (political and cultural in particular), as well as the institutional and organizational factors which determined the birth and the orientations given to the institutes specialized in Mass Communication in the three Maghrebian countries. Likewise, we will touch on the developments of Mass Communication Sciences in each of these three countries by asking the following questions: what foreign schools and trends did influence the orientations taken by Mass Communication Sciences in the Maghreb? What research methods and approaches dominated and why? What theoretical frameworks, and for what reasons? Thus, we propose to cover the aspects connected with teaching as well as those connected with research. Finally, we shall fix as an objective to identify how the stance of the key players regarding the policy adopted toward the field of Mass Communication (in terms of dependency or independency from other disciplines) favoured or not the emergence of a powerful academia tradition able to ensure its own legitimacy in the three countries. 


\section{LITERATURE REVIEW}

Mass Communication identity and legitimacy as a new discipline is relatively a new issue in the Maghreb; it has not been adequately addressed, and did not emerge as a major research concern until the late eighties. Furthermore, the first papers did not raise this issue with a specific concern of the North African under-region; Mass Communication in Maghreb was raised only indirectly by researchers who have approached this question within a larger concern related to Mass Communication status in the entire Arab world (Talal, 1993b). In addition to that, we note that contributions dedicated to Mass Communication in the three countries together are very limited, given that most of the papers did focus only on one country. Since 1982, articles that approached this question in Algeria Tunisia and Morocco separately were very abundant, especially for Algerian and Tunisian cases ; for instance, we can mention the contributions of Brahimi (1982) in Algeria "Journalism education and Mass Communication research in Algeria”, (Azzi, 1990) “Education in Mass Communication, conjunctions and oppositions between goals and means", (Z. C. Ramdane, 1990) “Journalists education within the ISIC”, (Laiadi, 1990)“ Mass Communication research indicators. As for Tunisia, we can mention the contributions of (Ben Cheikh \& Alhuwaidi, 1982) "Scientific Research In TV and Radio Broadcast in the Arab World: Facts and Questions on Tunisian Case ”, (Djendoubi, 1983) “Journalism Education”, (Hizaoui, 1987) “ Journalism between academic education and professional training”, (Moen, 1986) “ Journalism education in Tunisia and in the United States: similarities and differences. In Morocco we can mention only one single contribution; the one published by (Talal, 1993), entitled " Mass Communication education' experience in Morocco". We also have to highlight that except for a few rare studies, the focus of the majority of papers dedicated to this issue was put more on teaching aspects or research aspects without dealing with the question of a large perspective of Mass Communication advent, identity and legitimacy as a discipline.

The first attempt to approach the issue within the entire Maghreb area was the contribution of (Y. Ben Ramdane, 1987b), entitled "preliminary questions on the issue of Mass Communication education in the Maghreb". The author painted a negative portrait of the discipline and has referred the responsibility of this state to the first and second generations who were "unable to put in place a unified theoretical and methodological framework" for the discipline. Ben Ramdane judged that Mass Communication researches were very "limited in their theoretical, methodological and epistemological dimensions". Even if they were relatively important, quantitatively speaking, their "scientific value is still limited". He also criticized researchers who just followed the theoretical and methodological 
framework given, without trying to create their own one, saying that "the most important productions are only works that reproduce American theories and methods almost automatically". Thus these researchers became responsible for the shortcomings of Mass Communication research in the Maghreb.

The most comprehensive study that approached the issue of Mass Communication within the three Maghreb countries is the one conducted by Larbi Chouikha entitled "a draft reflection on the evolution of studies and research on the state of Mass Communication in the Maghreb " (Chouikha, 1994). In this study, Chouikha pointed out that the repeated failures to create a Maghreb association bringing together Mass Communication researchers illustrate the "ephemeral and non-institutionalized" character of Mass Communication research community in the Maghreb. He also highlighted the dominance of the empirical approaches in the three countries, a phenomenon he called the dominance of the "mainstream currents of thought" that have according to him "resisted the political and cultural evolutions of Maghreb societies". This dominance had favored "a segmented, reductionist and exclusively empirical approach". He also criticized these studies for their tendency to use mostly legal and historical approaches, and for being "too descriptive, quantitative and monographic".

Another study (Hammami, 2005) entitled "Information and Communication Sciences in the Arab World: Reflections on the difficulties of emergence of a discipline", has devoted a large part to the three Maghrebian countries. The study proceeded from the assumption that the dominance of “instrumental and technological representation of Mass Communication” in researcher's minds has freed the majority of them from any obligation to question the concepts and theoretical models they use spontaneously, unconsciously and routinely. The majority of Arab Mass Communication researchers "suffer from the lack of reflective attitudes and have very little analysis of their research practices", he said. This crisis of the reflection on the media and communication "is the result of an epistemological posture that has on one hand constantly cut off Mass Communication Sciences from its historical contexts of emergence and evolution, and on the other hand, isolated the understanding of Mass Communication as discipline of a human and social sciences interest". He also highlighted that Arab researchers "have evaded the philosophical problematic, the anthropological and historical aspects of the media and communication". Furthermore, Hammami pointed out that the negation of the historicity of communication and of the cultural models that organize it has thus "been expressed in the preference given to theoretical models favoring the study that focus mostly on senders and contents". 


\section{Essence and birth of Mass Communication in the Maghreb}

Journalism schools - launched right away for instrumental purposes just after the independence of the three states - were behind the establishments of current Mass Communication curricula in the three countries (Najar, 1987). After Tunisia, Morocco and Algeria recovered their sovereignty at the end of the Fifties and at the beginning of the Sixties, the political' priority in these three countries was to train professionals likely to guarantee the operation of medias institutions, suddenly abandoned by French media professionals just after they obtained independence (Azzi, 1990). This was probably one of the reasons why at that time, one still did not speak about "Mass Communication" but about "journalism and documentation".

The first country to institutionalize a formal curricula in journalism training was Tunisia, which launched in November 1956 a training session for journalists under the aegis of the State Secretariat of Information before creating within 'Bach Hanbah Institute', a training session for journalists in 1964 (Chouikha, 1994). On its part, Algeria launched two years after its independence, in 1964, the 'Higher Journalism School' under the aegis of the Ministry of Information (Azzi, 1993). Morocco had to wait until 1969 to create a 'Training Centre for Journalists' aimed at the retraining of newspapers' professionals (Talal, 1993a).

In the three mentioned countries, one shall note that the institutions created to ensure the training and retraining of journalists were placed - not under the supervision of the ministries of education, as we could have expected it - but under the supervision of the high authorities in charge of information. (i.e. the State Secretariat for Information in Tunisia and the Ministry of Information for Morocco and Algeria. At that time, journalism was considered in the three countries as a strategic sector that had to come under a regulating body with a coercive power such as ministries of information. This is due essentially to the fact that African and third world governments in general have adopted the notion of development journalism alternately with development communication in the 1960s (Ahmed, 2016) to underline the role of media in " mobilizing the masses towards the governments' project, persuading the people about the governments' intensions, and engaging them with the projects. (p. 440). Media institutions at that time were seen as instrumental tools for "dissemination of idea and knowledge", so governments can use them to create public awareness, increase knowledge, change attitudes, transform behaviour and foster engagement (U. Pate; S. Dauda, 2013). 
While Tunisia extended starting from 1967 the disciplinary field by leaving the reductive appellation 'journalism' after the creation of the 'Institute of Press and Information Sciences (IPSI)', Algeria and Morocco maintained for a long time the reductive 'journalism' appellation given to their journalism training schools and centres. It is only in 1982 that the Higher Institute of Journalism in Algeria changed its name to become the Institute of Information and Communication Sciences (which the equivalent name given to Mass Communication Sciences in the Maghreb as part of the French heritage), not without being first attached in 1976 to the Institute of Political Sciences under the name 'Institute of Political Sciences and Information'. As for Morocco, that the Higher Institute of Journalism was turned into 'the Higher Institute of Information and Communication' just in 1996 (Talal, 1993a).

When their training institutions were set up in Mass Communication, the three countries of the Maghreb got considerable financial support from the UNESCO (Y. Ben Ramdane, 1987). Moreover, these countries tried to diversify the partners who supported them in launching the training programmes, following the orientations imposed by their respective foreign political state policy. Thus, Morocco and Tunisia have traditionally cooperated with France, the Federal Republic of Germany (FRG), Belgium, Canada, Great Britain, and the USA. Algeria, for its part, has very quickly built up ties with Egypt, the USSR, the German Democratic Republic (GDR), Canada, Switzerland and Belgium. However, despite the will of diversification, many indicators show that the education and research institutions in the Maghreb, were, in a direct or indirect manner, influenced by the philosophy of the French social science in general, particularly by the spirit of French sciences of the mass communication. The influence was less problematic in Tunisia and Morocco where it occurred both indirectly - through teachers trained in French journalism schools - and directly, through cooperation agreements which openly connected the institutions of both countries to the French establishments.

On the other hand, the influence of the French Mass Communication philosophy and orientations on Algerian Mass Communication establishments had its ups and downs too. It went through a first period of direct influence connected to the presence of French instructors such as Francis Balle and Paul Balta (Z. C. Ramdane, 1990). Then, it experienced a period of indirect influence, when these establishments were under the influence of Algerian instructors, either French-speaking, or simply trained in French schools. We can mention, among many others, Brahim Brahimi, Nora Benallegue, Zoubir Chaouch Ramdan, Mohamed Abassa, Smaïl Haj Ali, Lofti Maharzi and Zouhir Ihaddaden, to only mention the most influential instructors and researchers of the time. Then, in a third period, 
instructors from Anglo-Saxon schools such as Abderrahamane Azzi, Mohamed Kirat and Saïd Boumaiza did introduce with success the Anglo-Saxon empirical approaches (Azzi, 1990). Finally, starting from the end of the Nineties, the Information and Communication department of the Faculty of Political and Information Sciences started to turn more towards the Arabic countries, as cultural exchanges and scientific cooperation were spurred on by a young Arab-speaking generation who graduated internally form the Information and Communication Sciences Institute (ISIC).

When Mass Communication curricula were set up in the Sixties, the three Maghrebian countries also turned towards the UNESCO, France, FRG, Belgium, Great Britain, the USA, as well as towards the countries of the Soviet bloc. Moreover, it is interesting to note that the resort to Egyptian expertise was expressed by the sending of experts whose mission was to become acquainted with the experience acquired by Egypt with regard to Mass Communication curriculum (Z. C. Ramdane, 1990). Welcoming Egyptian instructors, who were supposed to fill the vacuum of instructors of lecturing rank, also conveyed the will (Saoui, 1978). The resorting to the Egyptian experience also was governed by the concern of adapting the curricula to the Arab culture dimension and needs, but this orientation was limited in its effects by two obstacles: first by the nature of the Egyptian universities structures which were rather of an Anglo-Saxon inspiration, (and thus not adapted for structures and management styles inherited from the French system); then by the language barrier, given that at the beginning, Mass Communication establishments in the Maghreb taught most of their courses in French language.

This is why Mass Communication curricula remained mostly of French inspiration in Algeria, as in Morocco and Tunisia. But the supremacy of the French spirit was far from being approved unanimously: many academics pointed out some educational practices that favoured politicised analyses, or even some political commitments to the detriment of academic knowledge (Moen, 1986), (Azzi, 1990). What was directly called into question, was the French approach inherited from the Institute of Press (IFP) which focused mainly on the history of the media, the status of Media companies, the status of media contents as well as the professional status of journalists in the majority of the researches. It is therefore the study of Mass Communication in the French meaning of the term (i.e. the historical and critical approaches) opposed to the study of communication in the US sense of the term (i.e. the empirical study of the processes, tools and effects) that was in question. The supporters of the empirical trend in Mass Communication in the Maghreb came from Arab or Anglo-Saxon universities, whereas the partisans of the critical trend came from French universities or from 
universities of the former Soviet bloc. The debate, at the time followed on from the debate which tore up France in the Seventies related to the orientations to be given to French sociology; it opposed the partisans of macro-sociology and the defendants of micro-sociology (Azzi, 1993).

\section{A hybrid identity which poses a problem, in the Maghreb Region and elsewhere}

If in the rest of the world, Mass Communication Sciences started from the Seventies to emerge as an autonomous discipline, it was not the same in Maghreb where the discipline keeps on up to today suffering from the hybrid perception that political decision-makers and university players had of its identity. This is due to the confusing appellation given to the discipline; if the English appellation (Mass Communication) is more clear, the appellation - (Information and Communication Sciences) inherited from France, as the former protective or colonizing state, contains more meanings with large acceptances. The example of Algeria does reflect this reality; the discipline was indeed recognised in 1982 by the creation of the Institute of Information and Communication Sciences. But although the (ISIC) emerged between 1982 and 1998 as a leading institute at the University of Algiers, attracting on average 1,500 enrolled students per year just in under-graduation, a decree published on February 11, 1998 has established the creation of the Faculty of Political Sciences and Information. This decision reduced, de facto and once again, the discipline into a sub-domain of political sciences, and the Institute into an annex department of the Institute of Political Sciences. Thus the wording 'communication' disappeared, just like what happened in Tunisia where the same dimension was ignored during the first faltering attempts to establish the Institute of the Press and Information Sciences in 1967. We must specify here that until 1973, the IPSI was not recognised in Tunisia as an establishment, and that Mass Communication was not considered as an autonomous discipline as well (Chouikha, 1994). Students interested in Mass Communication had to enrol in one of the major programmes (sociology, arts, law...) and then had to take courses in Mass Communication as a complementary minor courses. One shall also note that the wording 'information sciences' transcribed by the last two letters in the name IPSI, is understood in a reductive acceptance since it is translated in Arabic by 'ôloum al-akhbar', which means 'sciences of news'.

Moreover, we note that the outlines of Mass Communication discipline in the Maghreb are still not quite marked in the minds to succeed in putting at distance the vague desires set out here and there by certain bordering disciplines which claim the appellation 'Information and Communication'. It is the case of Morocco where we note the existence if a higher school of information sciences, but which is 
aimed at training librarians and archivists. It is also the case of Algeria where, twice, the discipline of political sciences put its hands on the Information and Communication Sciences (which is, we should remember, the name used in the Maghreb for Mass Communication Sciences), and where the Research Centre in Scientific and Technical Information gives itself the legitimacy to represent Algeria in international colloquiums devoted to Mass Communication We can also mention that in Tunisia, some researchers working in the field of Library and IMS do not hesitate either to publish their researcher under the 'Info-Com' i.e. 'Mass-Comm' acronym.

Thus, it makes sense for certain to claim themselves from Mass Communication discipline, since it is the conjunction of Information Sciences on the one hand (understood in the sense of their beginning, i.e. library and information sciences, extended subsequently to computer science by the advent of ergonomics and information systems), and Communication Sciences on the other hand (understood in the sense of subjects dealing with media, culture and society). The problem does not concern only a bad will of one another, it is due to the semantic difficulty caused by the range of meanings given to the terms 'information' and 'communication' through history, or to the acceptance in which these two appellations are used in the three countries and elsewhere.

The proof is that the term 'information' may also encompass media and research contents as well as news or data. As regards the term 'communication', it can designate both transport means networks, and interpersonal exchanges or even telecommunication means/networks for instance. Thus, several disciplines of social science or technical sciences recognise themselves in either names, hence the confusion resulting from this situation. It is also true that the mathematic diagram behind the theory of information, proposed early in 1948 by Shannon and Weaver, did not help to give a clear definition of the object of Mass Communication. In cause, a model designed at the beginning for processing electronic communication, but used by social sciences and by technical sciences as well. From these different strange mixtures were born definitions which either tried to draw the object of Information and communication Sciences towards computer science and data processing, or tried to limit the object of the discipline to the contents recorded on media tools, others still limit it to information systems, etc...

This being said, we have to admit that the strange mixture between Mass Communication Sciences and its bordering disciplines and fields is not specific to the Maghreb; indeed, we find the illadvisedly use of the terms 'information' and 'communication' in Great-Britain and in the USA, where 
several research and education institutions carry the name 'School of Library and Information Sciences'. In France, we can note also that Information Sciences (Library Sciences, Archiving Sciences, IMS...) and Communication Sciences (sociology and history of the media, organisational communication...) are gathered within the $71^{\text {st }}$ section that define the fields of Mass Communication discipline. Moreover, the confusion as regards to the nature of the fields which could claim a classification under Mass Communication title obliged the national University Council (CNU) to publish in 1984 a text defining the domain of competence of Mass Communication Sciences, then to redefine the frame of the discipline again in three other times: 1993, in 1999 and 2005(Winkin, 2004).

This is to say how the field is changing, wide and permissive, and how those coming from scientific or from technical horizons far from Mass Communication Sciences find in their activities such or such aspect which connects them to the Mass Communication discipline. Thus, and in accordance with the framing text published in France in1984, the CNU recognized as coming under the Mass Communication umbrella all the following fields and subjects:

a) the studies that focus on the notions of information and communication, on their relations, on the nature and practices of the communication and information phenomena, as well as the different scientific approaches which apply to the discipline ; b) the study of the processes, productions and uses of information and communication on the one hand, the study of the conception and reception on the other hand, as well as the study of the processes of mediation and media coverage; c) the study of key individual or institutional players of information and communication, the study of professionals (including notably journalists) and their practices; d) the study of information, its content and its systems in terms of representations, meanings with the associated practices; e) the study of the media of communication and cultural industries in their various aspects (Jeanneret, Y. ; Ollivier, 2004)

If we examine carefully the delimitations brought by the context map imposed by the CNU text, we note that they are characterised by its too general formulations that push us to deduce that they have been worded not with a concern of clarification, but with the aim of including a maximum of key players claiming to be part of Mass Communication discipline. This concern of inclusion may perhaps be explained by the fact that at their start, Mass Communication Sciences needed the key players of these various fields to establish their foundation to constitute a discipline under construction and constantly evolving, hence the trend to extract the field from the exclusive domain of social science to 
draw it towards technical sciences (Devallon, 2004). But it must be said for its defense, that Mass Communication discipline is indeed at the intersection of several disciplines (philosophy, linguistics, computer science, sociology, etc.): consequently, displaying the interdisciplinary of the Mass Communication appeared as a necessity at that time. The carriers of this discipline have always claimed it very clearly and rightly, but in our opinion, the interdisciplinary dimension do take its meaning only if it is limited to the sole of borrowing methodological tools, and only if it curbs its encroachments on the objects of research of the other disciplines. Nowadays, the legitimate strives to build their own legitimacy through differentiating themselves from the literature, the linguistics, political sciences and other research fields, Mass Communication discipline is getting more and more closer to computer science and telecommunication. This new orientation is not without risk; it could spawn confusion again, and break out an identity that began just recently to unfold. The tendency to dissipate the discipline in several sub-disciplines, may harm the image and the legitimacy of Mass Communication discipline and may make more difficult the definition of its specific research object end field.

However, a solution may be envisaged by delimiting the frame of Mass Communication discipline and differentiate them from all the other bordering fields and disciplines. We can propose to carry out the following distinction:

is in the strict domain of Mass Communication, every object that comes under: a) the study of the diffusion or reception of the content thought by the issuing source with the aim of obtaining a special effect, transmitted one-way by involving at least one human intelligence (information); b) the study of contents thought by a transmitter within the framework of a process of interpersonal exchange which took place between two human intelligences simultaneously in transmission and reception role. (communication); c) the study of the institutional producers of contents grasped in relation to their background, legal status or economic and political aspects (media studies).

On the other hand we can consider that is of the strict domain of technical sciences (Computer sciences or IMS), every object that relates to the analysis of the media in the technical sense of the term, to the analysis of mediation tools, to the analysis of issues and/or receptions of content without taking into account the effect, and finally every subject that comes under data processing involving only machines or artificial intelligences. 
Once set, this frame may help in clarifying what is specific to Mass Communication Sciences and what is specific to other bordering disciplines, notably those listed under technical sciences as computer science, IMS and telecommunication. Our premise lies on the distinction made between information, as passive process on the side of the receptor, and communication which is an active process at the two ends of the communication scheme. Information as a social phenomenon is a unidirectional flow of content, but its flow cannot be grasped out of social meaning in terms of effect, whereas communication is mainly interested in the flows, effects and bidirectional and reciprocal process between two or several social key players.

Such a distinction will allow us to avoid the mixture of genres and protest 'assaults' suffered by Mass Communication discipline because of the misunderstanding of the terms "information" and 'communication'. Thus, the deliberate use of the participle in the phrase 'thought content' in the definition we gave to the term 'information', answers the need of clarifying that information understood in the sense of social science - cannot be tackled as a gross data outside any social, cultural or political significance. Information understood in its social meaning implies the idea of content with a meanings given by the human mind (at least at one of the ends of the information or communication diagram), the content serving a purpose for an effect aimed at by the issuing source. This clearly means that analysing a communication system, between two machines for instance, does not come within the field of the Mass Communication, which is - let's not forget - a discipline that belongs to humanities and social sciences not to technical sciences. On the other hand, analysing a content drawn up by a human mind and passed on by a machine to one or several human receptors remains in the field of Mass Communication Sciences.

This distinction will put de facto the discipline at a distance from all studies that deal with object from technical fields such as computer science, IMS, telecommunications and much more. Moreover, as we think that the field of Library and Archiving must be an independent field of Mass Communication Sciences, our distinctions shall prevent the preponderance of 'Library' part on 'information and communication' part, and shall even exclude the possibility of extending the field of Library Sciences to Mass Communication discipline. This is justified in our opinion by the fact that the main object of Library Sciences: (indexing, cataloguing ...) are the sciences and techniques which aims at knowing, managing and improving the means of placing at disposal of the receiver different mediums and tools, i.e. the mediation of containers from multiple designers/senders to multiple receivers. But 
unlike mediations studied by Mass Communication that focus - as we explained - on the key players and processes as well as on contents and social effects of the media, the ones tackled by Library Sciences are not interested either in the sender or in the receiver. Moreover, they are not interested either in the effects sought by the issuing source, nor those produced by the mediums they put at the disposal of the users. Finally, they are not interested in the content of these supports, apart from the superficial descriptions made for classification purposes.

\section{A field of research which toils to take off.}

We are now going to focus on the state of research in Mass Communication in the three Maghreb Countries with several indicators: productivity in research cycle, the number and quality of publications, the existence or not of research facilities, the share of the group research compared with the individuals efforts of research, the mediation and development of research on the regional and/or international scene, specialised magazines, the existence or not of corporatist structures bearing Mass Communication in these three countries.

From the start, we noted that in the first years of their creation, Mass Communication establishments in the three Maghreb countries seem to have given priority to the missions of vocational training they were in charge of by political authorities. Research cycles were introduced later on; Algeria instituted them only in 1977, Morocco in 1989 -knowing that the graduate studies were suspended for a long period - while Tunisia did introduce a graduate cycles only in 1993. Moreover, we have noticed that research productivity were very weak in Mass Communication, notably if we focus on the percentage of thesis defence comparatively to the number of students enrolled in graduate studies. In Algeria for instance, from 1978 to 1993, out of 2,250 enrolments and re-enrolments in master's degree and $\mathrm{PhD}$, no $\mathrm{PhD}$ dissertation was achieved and only 15 dissertations ended up in the master degree (Algiers University, 1994) This can be explained not only by the shortage of vocations among enrolled students, but also mainly by the multiple difficulties researchers encounter in an overall environment that is not in favour of research, whether in terms of financial funds support for researchers or in terms of access to information sources, libraries and data. Moreover, and except for some distinguished publications, the major number of papers are characterised by the preponderance of sterile descriptive studies to the detriment of the analytical or empirical approaches carrying new theories and/or conceptualisations. It is even strange to note that the fertility of research in Mass Communication in the 
Maghreb is more the privilege of undergraduate cycles, both as regards the diversity of the subjects tackled and as regards the methodologies used. Thus, the subjects tackled by graduation students are, according to their order of frequency as follows: 1- content analysis of the press, 2- the normative functions of the press, 3- sociology of the media, while we notice in undergraduate cycle that the dominant subjects are according to their order of frequency as follows: sociology of media, media content analysis from a political, cultural or educational perspective, then the study on the political aspects of the media, the history of the media, the semiology of the media, the legal status of the media, the technology of the media, and media economy.

Research in Mass Communication in the Maghreb also suffers from some dysfunction problems notably in terms of supervision both at the level of graduation and under graduation. In cause: three factors: the first one is connected with the disciplinary origin of Faculty members who teach in Mass Communication establishments in the three Maghreb countries. Many of them came from political sciences, sociology, history, economics, statistics or even from other fields. If the diversification may be explained by the necessity of ensuring the urgent need of covering all the courses offered in the common-core cycle, it cannot justify the fact that certain instructors foreigners to Mass Communication had more weight in decision-making process than the specialized faculty in Mass Communication discipline. The second factor takes back to the heterogeneousness origin of faculty members who graduate in the discipline; because of the shortage of instructors able to cover the whole course curricula, notably in the first years of their setting up, Mass Communication education institutes in the Maghreb resorted to the option of training abroad. By concern of independency and variation in terms of training schools, these establishments diversified the host countries of PhD students, hiring teachers educated in Arab, French, Belgium, UK, Russian, German or US schools, to mention only the major of them.

But the mixture of schools did not bring a productive diversity; on the contrary, it entailed divisions and antagonisms between the different trends arising from the ideological or philosophical differences between the different schools: communists, Arab, French-speaking, Arabic-speaking, English-speaking, Arab Nationalists, and much more. The third factor is connected with the stagnation of faculty specialized in Mass Communication; this is due to the absence of mechanisms aimed at renewing faculty teams following the same academic bases stated in developed countries, (i.e. a faculty member spots a PhD student and then hires him as assistant before giving him a permanent appointment 
as a lecturer). Furthermore, some major budget, bureaucratic and cronyism logics which dominated the recruitment process put a brake on hiring as well as on promotion of faculty already holding a position. This had for consequence an improper resort to assistant teaching and junior lecturers who did not held a post-graduation degree, not only for teaching but even for the supervision of undergraduate thesis.

One must also stress the absence in the Maghreb of research facilities worthy of this name (laboratories or research centres) within which research projects could be set up, organised and carried out. This is why research efforts in Mass Communication in the three countries of the Maghreb are characterised by the predominance of individual nature of productions. Moreover and as we underlined above, research efforts are more supplied by students dissertations (in bachelor's or master's thesis defense) than by faculty members. Some of the research produced in graduation are even of higher quality than some articles produced by faculty members themselves, both as regards to the originality of the object of the research or as regards to the methods used. Algeria was in the right direction however, since it had displayed in 1985 the will to create team research dynamic by instituting research units, in order to encourage faculty members and researchers to gather together in small thematic research teams. The goal of the decision-makers behind launching these research units was to institute them as an experimental step towards the creation of future laboratories, or even the future creation of interdisciplinary research teams. Unfortunately, this experience did not achieve its goals in Algeria because of the greatest economic crisis faced by the country in the eighties; hence, the financial and material means supposed to accompany the creation of this units were not afforded. Moreover, the operational setting up of the different research teams suffered from the timidity of faculty members and researchers, mainly attributable to the lack of visibility concerning the goals aimed at by the creation of these units, as well as the lack of visibility regarding operation mechanisms of these research teams (involvement on voluntary basis, absence of a statutory frame to regulate the relations within the units, absence of financial incentives ...). This is why in Mass Communication Sciences, only two research units have been created with teams comprising three researchers on average, without producing the expected outcomes that reflect research progress.

The scarcity of scientific production specific to Mass Communication faculty members in the three Maghreb countries is therefore explained not only by the financial problems and day-to-day problems mentioned below, but also by the absence of the statutory frame which pushes faculty and researchers to supply a minimum of publication each year. In developed countries, there are statutory 
frame which define the mechanisms of appointment and promotion, that creates a culture of creative competition between faculty members, thus favouring the emergence of dynamics of research and publication. But in the Maghreb the bureaucratic problems related to the statutory frames made them sterile, even generators of a destructive competition. Thus, problems of equivalence rating, problems of recognition of supplied publications, problems of differences on the criteria of educational and administrative researches' assessment, or even issues of political or ideological affiliation, blocked several associate professors in Mass Communication, who remained years without being promoted to full professors or from assistant to associate (Chabou, 1992). Moreover, junior lecturers (PhD students) could remain fifteen years in post without having to publish an article, or to defend their thesis. This acknowledgment brings us to mention here the absence in the Maghreb of the universal academic tradition which consists in encouraging $\mathrm{PhD}$ students to publish regularly on the significant parts of their research progresses. We cannot also ignore to mention the problem of the very limited accessibility of PhD student to specialised magazines and symposiums, notably due to the opacity surrounding the selection of articles and diffusion of calls for papers.

It is also impossible to ignore other obstacles related to the lack of mediation and valorisation suffered by Mas Communication research in the Maghreb, both with regard to the national/regional and international level. This problem is first attributable to the poor quality of most of research contributions which takes advantage of the systematic recourse to historical or descriptive approaches, avoiding therefore theorisation or conceptualisation efforts likely to advance the knowledge in Mass Communication. This problem is due secondly to the consequence of financial difficulties met by most Maghreb researchers who still isolated, despite their goodwill, from international research networks. The limited budgets devoted to scientific trips and conferences, or quite simply a limited access to foreign languages, push most of researchers to remain cloistered in their local or regional scientific sphere.

However, we notice a positive point which is that the three major establishments teaching Mass Communication in the three countries have their own specialized magazines publishing in three languages at least (Arabic, French, English): namely the Algerian Journal of Communication, the Tunisian Journal of Communication and the Journal of Research in Communication in Morocco. Even though the three journals may have a legitimate ambition to access to the universality given their regularity and the high quality of peer reviewed articles, minor insufficiencies and problems make that 
even with international quality papers, their echo does not exceed the scientific circle of the local area except for the Tunisian Journal. Are notably in cause here the non-affiliation of the magazines to research units or labs which would give them a more academic legitimacy, the absence of thematic issues in publication, the absence of translation of the important researches produced in Arabic, the absence of international standards and protocols of publication especially with regard to the ISBN or ISNN numbers, (those were introduced only recently).

All these insufficiencies discouraged researchers and pushed them to publish in magazines with international standards. The absence of development of active research in the Maghreb is also attributable to the lack of visibility of its key players on international scientific scenes. This is due first to the problem related to the diffusion of calls for communication because of the absence of networks that can centralize that calls and disseminate them to the concerned establishments. This is secondly due to budget restrictions that made the participations to international conferences and symposiums very sparse.

Finally, it is important in our opinion to stress the non-existence in the three Maghrebian countries of corporatist structures, likely to carry Mass Communication in the three concerned countries by legitimating them as a scientific discipline under social science. Although the tradition of scientific associations is starting to develop in the three concerned countries, it is only at its nadir in humanities and social sciences, and it is almost non-existent in Mass Communication discipline. For the time being, the work of mutualisation of resources and research efforts is mainly restricted to technical fields, which aim to represent Mass Communication discipline, i.e. computing and library sciences. The associative activities of these branches seem to be more aimed at promoting the rooting of these branches to Mass Communication discipline rather than legitimizing the discipline in an institutional environment, which, most of the time, considers Mass Communication Sciences as a sub discipline. As regards the Mass Communication key players specifically, we notice that they distinguish themselves by their chronic absence in terms of collective or associative action, often leaving the decision-making process on the major issues of the discipline to the sole university or ministerial administrations. Because of the absence of Mass Communication expertizes and representations, they do build the major policies and decide of the major directions to be given to the discipline according to the sole bureaucratic and/ or budget considerations. 
When one knows the role that scientific associations in Mass Communication Sciences played in the USA (from the American Association for Teachers of Journalism created as early as 1912 to the American Communication Association since 1993), in France (the SFSIC since 1974, the Media History Society since October 2000) or even in Canada (the Canadian Association of Communication since 1980), they may reasonably wonder why researchers specialised in pure Mass Communication in the Maghreb do not realise the need to create their own ones, both at national and regional levels. The heterogeneousness already mentioned, whether due to the discipline of faculty's belonging (Mass Communication or other) or to the original education schools (Arabic-speaking, French-speaking, English-speaking, communists, liberal...) added to the political or ideological antagonisms it induced, may be an answer. The absence of association culture due to the lack of freedom of association which lasted until the Nineties in Algeria and until recently after the Arab Spring in Tunisia and Morocco, may also justify in part this established fact, in addition to the absence of means made available to researchers. However, it seems to us that there is a problem of institutional culture connected with the absence of a tradition of research and publication. In front of the inertia of public authorities who do not want to put the necessary means for the development of research in humanity and social sciences and which, and who moreover, tend to see humanities and social sciences universities as only teaching centres, faculty and researchers end by adapting to an institutional reality where instructors are appreciated only for their teaching contributions. Furthermore, facing the absence of financial incentives in addition to the absence of educational discharges which would help them to devote themselves to research, faculty no longer see the necessity of proving research excellency. But history shows us that in all developed countries, Mass Communication have been carried by scientific groupings, not by administrative hierarchies; indeed, they are the scientific associations who created research dynamics, while the role of the states often limited itself to only providing facilities and financial means. In the Maghreb, it is deplorable to notice that researchers specialised in Mass Communication, rather than doing their best to initiate changes likely to disrupt their disciplinary field at the universities, seem to put up with a state management which finally is convenient for everyone, but which is carried out to the prejudice of the discipline identity, legitimacy and excellency. 


\section{CONCLUSION}

Historically of a French philosophical inspiration and of a French tongue until recently, Mass Communication Sciences in the Maghreb are starting to benefit from the contribution of generations graduated in Arabic-speaking and English-speaking schools. Consequently, the discipline is turning more and more towards the Anglo-Saxon sphere to draw theoretical frameworks and methodological tools able to meet the demand, more and more urgent, to move away from speculative studies to focus on concrete social problems by resorting to empirical methods but this new tendency is not going without reviving the debate between the advocate of functionalism and supports of criticism. Mass Communication discipline in the Maghreb still suffers therefore from the same epistemological questioning as the discipline did it in France and elsewhere: should one give the pre-eminence to microsociology or to macro-sociology? Should one prefer the supremacy of the university theoretical calling or the supremacy of the professional and technical calling? Moreover - and although the discipline suffered in the Maghreb from the lack of visibility regarding its identity - alike what happened in developed countries when Mass Communication started emerging -, the path of recognition of Mass Communication discipline in the Maghreb does not seem to take the same direction as the one taken by Mass Communication Sciences in France. This is probably due to the narrowness margin of manoeuvre left to Mass Communication establishments and key players on the Southern shores of the Mediterranean Sea.

Thus, although they are often handled roughly by the different restructuring tending to reduce the discipline into a sub-discipline, Mass Communication have not found a spokesperson posing the question of the place of this discipline in the university scene in the three concerned countries. Even worse, the recognition of this discipline does not even emerge as a problem, either in specialised literature, or in the university debates, which indicates a problem of identity among the university key players of Mass Communication discipline themselves. In the absence of 'founding fathers' influence with the academic legitimacy to modify the directions given to the discipline, and because of the shortage of corporatist structures capable of bringing a scientific expertise to administrative decision makers in order to defend the interest of the discipline, Mass Communication sciences are marginalized in the Maghreb and did not enjoy the same recognition as those acquired by the discipline in France and elsewhere. Thus, the institutional base given to Mass Communication Sciences in the Maghreb seems to favour educational calling to the prejudice of research calling. Subject to political conformism that 
channels research interests towards non polemical subjects - which limits de facto its research objects-, derisory both by its quality and by its quantity, invisible and marginalised by the shortage of valorisation mechanisms, Mass Communication research in the Maghreb was not in the past able to favour the emergence of a thought likely to ensure its own recognition in the university environment at first, nor to be accepted as an entire discipline in the public space secondly. Fatalists, faculty and specialized researchers in Mass Communication resigned themselves to accept that other faculty from other bordering disciplines take more important weight in the decision-making within their own establishments. The loss of recognition as well as the absence of visibility of the ideas brought by Mass Communication Faculty in the public space caused that several times (this is true in particular for Algeria), the media dealing with subjects related to Mass Communication issues resorted to the expert appraisals from sociology and political sciences rather than to faculty and researchers specialised in Mass Communication.

However, we cannot hide a number of indicators, which show an ineluctable evolution of this discipline in the three Maghrebian countries. For several years indeed, one can note the decentralization of Mass Communication establishments in Algeria, which are now established as departments in several universities of the provinces (20 in total). Moreover, we note that here and there, initiatives are taken to help Maghreb Mass Communication Sciences to access international level. We thus note that for many years, very efficient forms of collaboration and exchange with US, European and Arab universities have been created in Tunisia and Morocco. The most fruitful initiatives in terms of publication and research probably remain those of the IPSI of the University of Mannouba, in Tunisia, which launched bilateral and multilateral research projects with European universities and research centres (Unesco, 2012). These activities allowed faculty and researchers from the IPSI to not only develop their work by gaining access to international research networks, but also to improve the quality of their work (in terms of scientific interest, research objects as well as their worldwide visibility). In Algeria, we also noted that an attractive status of researcher was recently stated with the ambition of creating a permanent research dynamics. These assets, despite being very limited, can only favour a race towards excellence between the Maghreb establishments teaching Mass Communication. Moreover, the young generation of instructors and researchers is more inclined to put ideological and language quarrels aside, in order to take advantage of the excellent communication means - the Internet - to form associations which work towards achieving a double purpose: first, by putting together the efforts and resources in order to cause to emerge a quality research in Mass Communication, and then, by making up this discipline's identity, 
in order to be able to bring forward its recognition and respect within social sciences, and make it the avant-garde of humanities and social sciences.

\section{ABOUT THE AUTHOR}

Dr Kamal Hamidou is a $\mathrm{PhD}$ holder from Paris2 - Sorbonne University. He is currently an assistant professor in Mass Communication Department at Qatar University. He has an international teaching experience as he taught before at Metz University in France as well as at the UAE University. His main research interest is sociology/usages of television and New Information and Communication Technologies as an extension of his doctoral research. His interest in TVs and smart devices comes within the scope of studying the influence of communication contents, processes and systems on social processes and sociocultural change, as well as on perception and cognition processes.

Dr. Kamal Hamidou,

Mass Communication Department, Qatar University - P.O. Box 2713, Doha, Qatar.

Professional e-mail: kamal.hamidou@qu.edu.qa; hamidoukamal24@gmail.com 


\section{REFERENCES}

Ahmed, I. S. Y. (2016). Development Journalism and Its Political Contribution to the State Building: The Case of Somalia. Malaysian Journal of Communication, 32(1), 437-454.

Algiers University. (1994). Directory of thesis defended at algiers u niversity. Algiers: OPU.

Azzi, A. (1990). Education in Mass Communication, Conjunctions and Oppositions Between Goals and Means. Algerian Journal of Communication, 4, 7-41.

Azzi, A. (1993). Research in Social Sciences : Some Comparisons and Priorities. Algiers University Annals, 7, 39-69.

Ben Cheikh, A., \& Alhuwaidi, F. (1982). Scientific research In TV and radio broadcast in the Arab World: Facts and questions on Tunisian case. Researches Journal, 7(Special issue), 17-28.

Brahimi, B. (1982). Journalism education and mass communication research in Algeria. Communication Journal for Population Development and Construction, 28, 106-119.

Chabou, M. I. (1992). Assessing high education reforms: between political issues and pedagogical requirements on scientific criteria. Algiers University Annals, 6(1), 25-32.

Chouikha, L. (1994). A draft reflexion on the evolution of studies and research on the state of mass communication in the Maghreb. Tunisian Journal of Communication, 25(1), 25-33.

Devallon, J. (2004). Concret object, scientific object, research object. Hermes, 38(1), 30-37.

Djendoubi, M. (1983). Journalism education. Tunisian Journal of Communication, 3(1), 29-40.

Gitlin, T. (1978). Media sociology: The dominant paradigm. Theory and Society, 6(1), 205-253.

Hammami, S. (2005). Information and communication sciences : reflexion on the difficulties of the emergence of a discipline. Tunisian Journal of Communication, 45(1), 6-34.

Hizaoui, A. (1987). Journalism between acdemic and professional trainings. Tunisian Journal of Communication, 11(1), 39-40.

Jeanneret, Y.; Ollivier, B. (2004). The problematical inevent of a field. Hermes, 38(1), 27-29.

Katz, E. (1987). Communication research since Lazersfeld. Public Opinion Quarterly, 51(4), 25-45.

Laiadi, N. (1990). Mass Communication Research indicators. Algieran Journal of Communication, $4(1), 63-73$.

Miege, B. (2004). Political economy of mass communication. Hermes, 38(1), 46-54.

Moen, D. (1986). Journalism education in Tunisia and in the United States. Tunisian Journal of Communication, 10(1), 103-106.

Najar, R. (1987). Mas communication education in the Maghreb: Reality and prospects. Tunisian Journal of Communication, 11(1), 9-16. 
Ramdane, Z. C. (1990). Journalism education within the information and communication sciences institue. Algiers University Annals, 7, 223-236.

Ramdane, Y. Ben. (1987a). Preliminary questions on the issue of mass communication education in the Mghreb. Tunisian Journal of Communication, 11, 7-12.

Ramdane, Y. Ben. (1987b). Preliminary qusetions on the issue of mass communication education in the Maghreb. Tunisian Journal of Communication, 11(1), 7-12.

Saoui, A. H. Al. (1978). Mass communication education in the Arab World. Riyadh: University Press.

Shramm, W. (1959). C omments on berelson's article. Public Opinion Quarterly, 23(1), 6-9.

Talal, M. (1993a). Mass Communication education in Morocco. Communication Journal for Population Development and Construction, 27(1), 55-65.

Talal, M. (1993b). Mass communication in the Arab world: objects and approaches (1st ed.). Rabat: Moroccan Company for Publication.

U. Pate; S. Dauda. (2013). Media and socio economic development in northern Nigeria. Malaysian Journal of Communication, 29(1), 1-19.

Ugboajah, F. O. (1987). Current debates in the field of mass communication Research : an african viewpoint. African Media Review, 1(2), 1-17.

Unesco. (2012). Study of media developpment in Tunisia. Paris: Unesco.

Winkin, Y. (2004). About some American origins of communication sciences. Hermes, 38(1), 103110. 